\author{
Aneta Pawłowska \\ ๑ https://orcid.org/0000-0003-2847-4403 \\ Institute of Art History \\ University of Łódź \\ aneta.pawlowska@uni.lodz.pl
}

\title{
THE WHITE MAN'S BURDEN'. FROM COLONIALISM TO POSTCOLONIALISM - DISCOURSE ON NON-EUROPEAN ART AND ITS POSITION IN THE ARTWORLD FROM THE PERSPECTIVE OF THE 2020S
}

\begin{abstract}
The purpose of this paper is the presentation of a historical perspective to assess the impact of 19th-century European colonization on culture and art. The article discusses the changes that have taken place over the years in the approach to the non-European population as well as its art and culture. From the sense of "the civilization mission of white people" (which is reflected in the poem The White Man's Burden) in the 19th century, through the interest in tribal art of European Avant-garde artists in the early 20th century, to the period of the beginning of discourse on the negative face of colonialism (e.g. Discours sur le colonialism by Aimé Césaire or visual actions by Ben Enwonwu, Ernest Mancoba). Particular attention has been paid to modern times and settling accounts with colonialism. This trend has been more and more visible since the end of the 1980s (e.g. the controversial Magiciens de la Terre (Paris) exhibition from 1989 or the Documenta exhibitions curated by non-Europeans (e.g. Okwui Enwezor). The period of the 21st century is dominated by the postcolonial trend in art (recognized artists of this profile include Fred Wilson (b. 1954), Sonia Boyce (b. 1962), Kara Walker (b. 1969), Hew Locke (b. 1959), Yinka Shonibare (b. 1962) and Kader Attia (b. 1970)).
\end{abstract}

Keywords: postcolonialism, colonial conquest, discourse, art, Africa, collections

\section{Introductory remarks}

19th century colonialism was a time of significant military power and economic prosperity for Europeans. Thanks to the rapid development of trade and

1 R. Kipling, The White Man's Burden, “Literature”, February 4, 1890, p. 115. 
industry, Europe has openly recognized itself as the true 'ruler' of the rest of the world. This widespread belief in the greatness of Europe caused the expansion of the largest and richest countries of the old continent to previously unknown wildlands. The pressure to conquer new lands and colonize them was so great that even countries with broken statehood in the 19th century, such as Poland and the Czech Republic, had their representatives among colonizers. It is enough to mention here the following names from the period of Polish partitions: Jan Czekanowski, Jean Thadée Emmanuel Dybowski, Antoni Rehman, Adam Sierakowski or Stefan Szolc-Rogozinski. In the Czech Republic, the famous doctor and traveler - Emil Holub (1847-1902) ruthlessly conducted research in South Africa ${ }^{2}$. All of the above-mentioned travelers helped both support the exploration of new lands and often prepare bases there for emigrants who were oppressed in their European homelands.

Consequently, millions of Africans, Asians and other peoples were subject to the colonial rule by overseas empires until the mid-20th century. Today, the colonial period is commonly viewed negatively, while the political, cultural and economic remnants associated with it are often condemned by both the colonized and colonizing countries. In 1960, the United Nations proclaimed Resolution 1514, and in this document condemned colonialism as "exploitation that constitutes a denial of basic human rights." 3 Over time, changes related to international norms of relations between states allowed for the development (sometimes in turbulent and dramatic circumstances) of political and economic independence of colonial states from the metropolises. Gradually, by the end of the 20th century, nearly all of these peoples became citizens of independent nation-states. However, in the sphere of culture and art, there are still many unresolved questions and problems concerning the colonial period.

Nowadays, one of the key problems associated with contemporary discourse $^{4}$ on colonialism is the question about artifacts from non-European cultural backgrounds. A simple solution to include art created by non-Westerners in the discourse and museum collections seems to be insufficient. How should

2 Issues connected with Emil Holub's work were the subject of the author's research internship at the University of West Bohemia (Pilsen) [Západočeská Univerzita v Plzni] in the Czech Republic, financed by the Polish National Agency for Academic Exchange (NAWA) AGREEMENT No: PPN/BIL/2018/1/12/CZE/UMOWA/1.

3 D. Kenedy, Decolonization: A Very Short Introduction, London: Oxford University Press, 2016, p. 11.

4 Speaking of contemporary discourse, one should add that although it is used passionately by the most prominent intellectuals of the second half of the 20th century, each of them understands the word differently. This does not mean, however, that 'discourse' is a word that means nothing. 'Discourse,' which means 'running back and forth' from Latin, is therefore nothing but an exchange of opinions and thoughts, a conversation, an interaction of different social groups. 
these non-European creations be viewed - as works of art or objects in an ethnographic context? And another equally important question in the vein of decolonization is whether countries such as Germany, the Netherlands, the UK and France should return works of art looted during the colonial period. Another critical issue that should be considered is the question of what our understanding of 'decolonizing art history' is now. All of these questions are strongly connected with the modern-day phenomenon of so-called Global Art. ${ }^{5}$ One could ask why this discourse is so important. At this point, we should recall the classical colonial debate ${ }^{6}$ proclaiming the necessity of domination of the white race and Western culture. From the mid- to the late 19th century, colonialism was presented as 'the extension of civilization,' which ideologically justified the self-ascribed racial and cultural superiority of the Western world over the non-Western world. This concept was presented by Joseph-Ernest Renan (1823-1892) in La Réforme intellectuelle et morale (1871)7, whereby imperial stewardship was thought to affect the intellectual and moral reformation of the colored peoples of the lesser cultures of the world. An excellent example of his judgments and opinions could be this quote:

"The regeneration of the inferior or degenerate races, by the superior races, is part of the providential order of things for humanity (...). Regere imperio populos is our vocation. (...) Nature has made a race of workers, the Chinese race, who have wonderful manual dexterity, and almost no sense of honour; govern them with justice, levying from them, in return for the blessing of such a government, an ample allowance for the conquering race, and they will be satisfied; a race of

5 In recent years, 'global art' has become a catchphrase in many contemporary art discourses; read more in: J. Zarobell, Art and the Global Economy, Berkeley-Los Angeles-London: University of California Press 2017 and J. Lack, Global Art, London: Thames \& Hudson Ltd, 2020.

6 The concept of colonialism is understood as a practice or policy of control by one people or power over other people or areas, often by establishing colonies and generally with the aim of economic dominance. The Stanford Encyclopedia of Philosophy uses the term "to describe the process of European settlement and political control over the rest of the world, including the Americas, Australia, and parts of Africa and Asia." It discusses the distinction between colonialism, imperialism and conquest, and states that „[ $\mathrm{t}]$ he difficulty of defining colonialism stems from the fact that the term is often used as a synonym for imperialism. Both colonialism and imperialism were forms of conquest that were expected to benefit Europe economically and strategically," continuing: "given the difficulty of consistently distinguishing between the two terms, this entry will use colonialism broadly to refer to the project of European political domination from the sixteenth to the twentieth centuries that ended with the national liberation movements of the 1960s." After M. Kohn Colonialism, in: Stanford Encyclopedia of Philosophy, Palo Alto: Stanford University, https://plato.stanford. edu/entries/colonialism/ (13/06/2021).

7 E. Renan, La Reforme Intellectuelle et Morale, Paris: Calmann-Levy, 1929. 
tillers of the soil, the Negro; treat him with kindness and humanity, and all will be as it should; a race of masters and soldiers, the European race (...). Let each do what he is made for, and all will be well."

Thus, the starting point for Renan's reflection was the strong belief that the European race is a race of masters. The white race is, according to these views, predestined to rule over other people of the world. Another important element of this puzzle was a systematic depreciation of African culture. As Cedric Robinson points out in his influential book Black Marxism

“(...) an entire [added by AP] generation of <<enlightened〉> European scholars worked hard to wipe out the cultural and intellectual contributions of Egypt and Nubia from European history, to whiten the West to maintain the purity of the $<<$ European $>$ race. They also stripped all of Africa of any semblance of $<<$ civilization $>>$, using the printed page to eradicate African history and thus reduce a whole continent and its progeny to little more than beasts of burden or brutish heathens."

The result of this approach to world history is the fabrication of Europe as a distinct, racially pure entity, solely responsible for modernity and progress. Moreover, in the 19th century this was seen as its moral duty to carry the socalled "muzzle of education" to the rest of the continents. On the other hand, Europeans had quickly come to fear and hate physical proximity to their nonwhite subjects - their "new-caught sullen peoples", as Rudyard Kipling (1865-1936) - the British Victorian poet and novelist - called colonized Asians and Africans in his 1899 poem The White Man's Burden ${ }^{10}$ (considered a the hymn to Imperialism).

\section{The civilizing mission of whites in the 19th century}

Undoubtedly, the racialist group-identity language used by white people justified geopolitical competition between the European and American empires. Additionally, in the colonization of the Far East and so-called Scramble for Africa in the late 19th century, the representation of a homogeneous European identity justified colonization. Thus, Belgium, Britain, France and Germany

8 Ernest Renan quote from Aimé Césaire, Discourse on Colonialism, trans. Joan Pinkham, New York: Monthly Review Press, 2000, p. 38.

9 C. Robinson, Black Marxism: The Making of the Black Radical Tradition, Chapel Hill, NC: University of North Carolina Press, 2000, p. XIII.

10 R. Kipling, The White Man's..., p. 115. 
proffered theories of national superiority that justified colonialism as delivering the light of civilization to unenlightened peoples.

As Kipling presents it in the abovementioned poem The White Man's Burden, the conquering of non-white races was seen as white people's selfless moral duty. This conquest, according to the poem, is not for personal or national benefit, but rather for the gain of others - specifically, for the gain of the conquered. The white race will "serve [their] captives' need" rather than their own and the white conquerors "seek another's profit, / And work another's gain." Even if they do not recognize their benefit, non-white races will be brought "(Ah, slowly!) toward the light" and escape the "Egyptian night" in which they idled before their conquest. Yet, non-whites' positive sentiment for their own "darkness" 11 indicates the extreme difficulty whites will face in seeking to educate the conquered peoples. The concept of la mission civilisatrice ${ }^{12}$ of the French Empire proposed that some races and cultures have a higher purpose in life, whereby the more powerful, more developed and more civilized races have the right to colonize other peoples, in service to the noble idea of 'civilization' and its economic benefits. According to such statements, the British colonized Africa around 1870. The colonial conquest of Indochina by the French and the Dutch subjugation of the Dutch East Indies continued simultaneously. Thus, starting in the 1870s, thousands of African sculptures, as well as Indonesian, Chinese and Japanese artifacts arrived in Europe in the aftermath of colonial conquests and exploratory expeditions.

This kind of egotism and arrogance of the leaders of the superpowers at that time was a stimulus for artists to address this subject in the form of caricatures which, in our opinion, were one of the forms of media that could convey the character of the colonial era. An appropriate example could be the caricature created by Edward Linley Sambourne (1844-1910), entitled In The Rubber Coils. Scene - The Congo 'Free' State" which presents the greed of King Leopold II of Belgium, who exploits an African from the Congo collecting local wealth - rubber gum. The ruler, who owned the Congo ${ }^{13}$, cruelly robbed it of rubber and ivory, drawing profit from forced labor of the natives. [Fig. 1]

The vision of Africa and its inhabitants as a Dark Continent allowed many critics and art lovers to ignore its artistic expression and not to treat its creations as works of art (and its creators as artists) but strictly as bizarre objects

11 Ibid.

12 Cp. H. Liebersohn, Harry M., Introduction: The Civilizing Mission, "Journal of World History," vol. 27, no. 3, 2016, pp. 383-387.

13 The Congo Free State, also known as the Independent State of the Congo (French: État indépendant du Congo), was a large state in Central Africa from 1885 to 1908. It was privately owned by Leopold II of Belgium. 


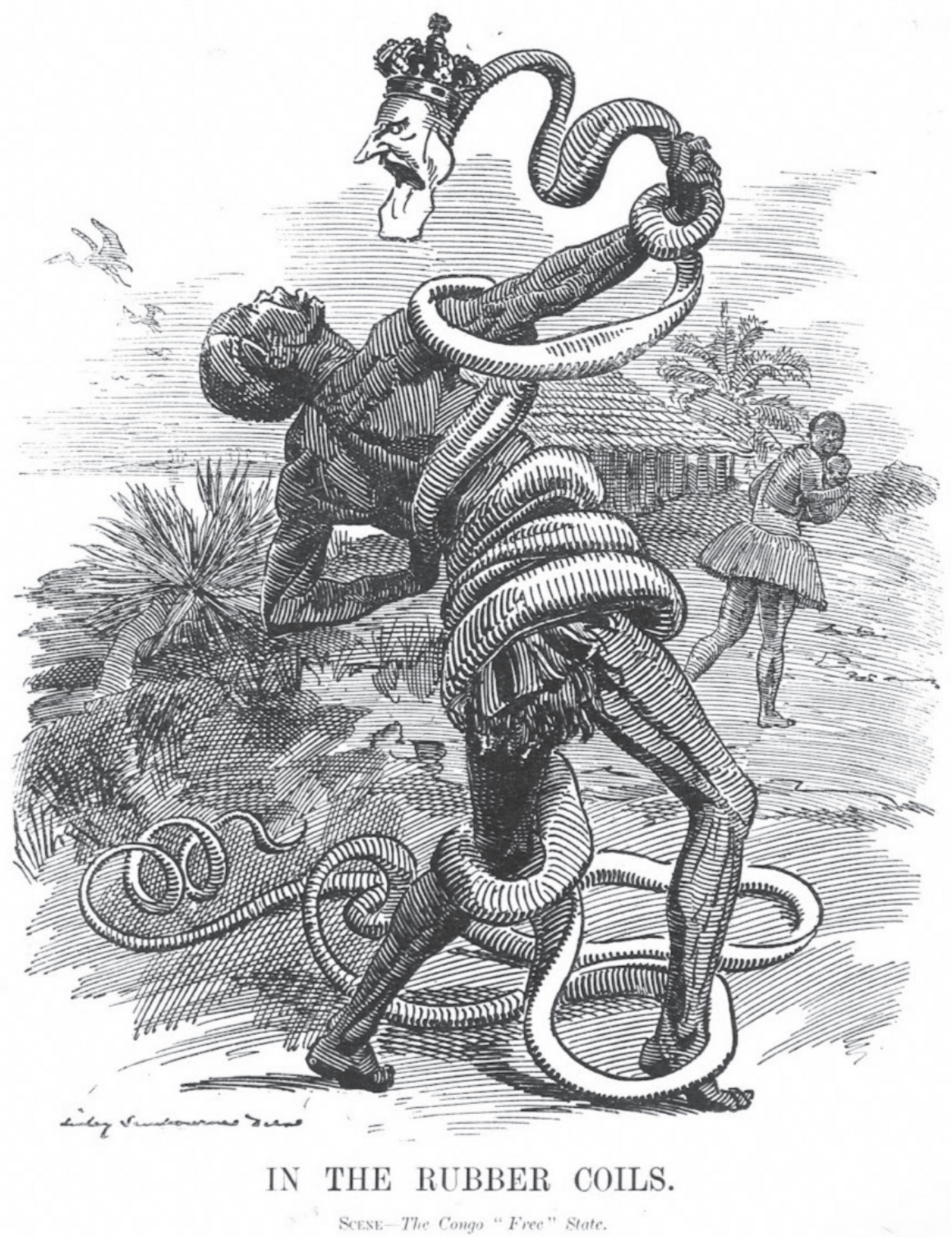

1. Edward Linley Sambourne, In The Rubber Coils. Scene - The Congo 'Free' State”, 1906 (commons. wikimedia.org) 
whose proper place was at best in ethnographic museums. Opinions and attitudes towards its art were also determined by preconceived ideas and philosophies about race and, therefore, its creations were not categorized as true 'art' in the Euro-American sense of the word. Therefore, non-European art objects were placed on view in various museums, such as the France Musée d'Ethnographie du Trocadéro and its counterparts in other European cities, e.g. Berlin Museum für Völkerkunde and Koninklijk Museum voor Midden-Afrika situated in Tervuren in the Flemish Brabant in Belgium, just outside of Brussels. At the time, these objects were treated as the artifacts of colonized cultures rather than as artworks and were very cheap, often sold in flea markets and pawnshops. The recognition of these ethnographic curiosities as art was not immediate. Deeper consideration concerning objects originating from Africa emerged at the turn of the 20th century. It was only then that celebrated literary works, such as Heart of Darkness ${ }^{14}$ by Joseph Conrad (1857-1924), started to present colonialism, especially in the Congo, not only as a great achievement but also as a truly destructive force which not only drastically exploited the continent but also degenerated its inhabitants and corrupted their native culture.

\section{New trends in contemporary art in the early 20th century and increasing appreciation of tribal art}

Suddenly in the 1900s, the French Avant-Garde art movement in Paris (including Pablo Picasso, Georges Braque, Henri Matisse, Maurice de Vlaminck and Andre Derain) began to take a vivid interest in sculpture originating in West and Central Africa, noticed by art historians due to its influence on their work. ${ }^{15}$ This was particularly appealing to those seeking creative inspiration from various impulses which their own culture defined as intuitive and primitive.

Such interpretations were founded on the myth of a 'primitive man', which explains and tells more about Western culture that created it than about other cultures it was so readily applied to. Myths of the 'primitive man' serve as imagined alternatives that may both justify and challenge Western culture and civilization as it is often defined. In various times and places, these myths have employed either demonic images of childlike but bestial savages and ignorant

14 J. Conrad, The Heart of Darkness, "Blackwood's Magazine”, February 1899-April 1899, vol. CLXV, pp. 164-460, 460-621, 620-781.

15 To read more: W. Rubin, (ed). Primitivism in 20th Century Art: Affinity of the Tribal and the Modern. New York: The Museum of Modern Art, vol. 1-2, 1984; A. Pawłowska, Picasso i Afryka, "The Artistic Traditions of non-European Culture", 2009, vol. 1, pp. 163-173 and Eadem, Avant-gardists and primitivism, "Art Inquiry. Recherches sur les arts", 2017 vol. XIX, pp. 153-169 as well as J. Flam, Jack \& M. Deutch, Primitivism and Twentieth-Century Art: A Documentary History, Berkeley: University of California Press, 2003. 
backward peasants, or utopian visions of noble savages and primal tribal peoples living in harmony with nature. ${ }^{16}$ This romantic trope of primitive simplicity and purity has deep roots in Western culture and art. It is evident, for example, in Paul Gauguin's search for both a simple life during his stay among Breton peasants and his escape to an exotic life among Tahitians. It can also be seen in utilizing non-Western art and ritual practices by the European AvantGarde before the First World War (i.e. Cubism, Fauvism, Die Brücke) ${ }^{17}$.

Quite a similar attitude was presented by Auguste Macke (1887-1914), an outstanding German painter who was the leader of Der Blaue Reiter. He suggested that the creativity of African peoples was worth more to European visual culture than had originally been appreciated. He was shocked by the way "connoisseurs and artists [had A.P.] (...) banished all forms of primitive cultures to the fields of ethnology or applied arts" 18 and felt that, despite stylistic differences, all art was created to give a visual form to all intangible ideas, which is an intrinsically human trait.

Even after the Avant-Garde art movement of the early 20th century had ended and many of the artists themselves had lost all interest in African art, the market for African art, which they had inspired and helped organize, had already developed its own commercial and economic structure, enabling it to continue growing and to flourish without their support. Initially, however, in early 20th-century Europe, positive reception and approval of African objects purely as fine art was largely limited to private galleries. In Paris, for example, dealers such as Paul Guillaume, Charles Ratton and Louis Carre played a role in the formation of major private collections of African art. One can observe a similar attitude to African artifacts presented by Stewart Culin (1858-1929), curator of the Department of Ethnology at the Museum of the Brooklyn Institute of Arts and Sciences, who was among the first curators to recognize the displayed ethnological collections as true art objects and not only ethnographic specimens. His approach is evidenced in his exhibition entitled Primitive Negro Art, Chiefly from the Belgian Congo. The exhibition opened in April 1923 and showed the African objects he had acquired in Europe from various dealers. ${ }^{19}$ As Culin stated in the exhibition catalogue:

16 J-J. Rousseau, The Social Contract, J. Bennett (ed.) 2017, www.earlymoderntexts.com/assets/pdfs/rousseau 1762.pdf, (13/06/2021).

17 To see more: R. Goldwater, Primitivism in Modern Art, Cambridge-Massachusetts-London, Harvard University Press, 1986, pp. 167 et al.

18 A. Macke, Masks, in: Ch. Harrison \& P. Wood (ed.), Art in Theory, 1900-2000: an anthology of changing ideas, Oxford: Wiley-Blackwell, 2002, p. 96.

19 African Art Exhibition of 1923, https://www.brooklynmuseum.org/opencollection/research/ pna1923, $(13 / 01 / 2020)$. 
"Apart from private exhibitions, designated as artistic, the objects of Negro art which are displayed publicly form part of museum collections of African ethnology and receive no special attention at the hands of ethnologists. The most notable collection is in the Museum of the Congo at Tervueren, Brussels, Belgium. Enormous collections exist also in the museums of ethnology of Berlin and other German cities, in London in the British Museum, in Paris at the Trocadero and in America in Washington, Philadelphia, Cambridge, Chicago, and in New York where the Museum of Natural History contains a vast hall of African ethnology in part derived from the Belgian Congo and presented by $\mathrm{H}$. M. the King of the Belgians. In the majority of these collections, their artistic significance is obscured by the wealth of material, and lost, not infrequently, in the efforts made for its elucidation." 20

At the beginning of the 20th century, as was already mentioned above, African forms and aesthetics stimulated a slowly rising demand for African $\operatorname{art}^{21}$ objects in Europe. At first, the demand was limited largely to the Cubists, their immediate entourage and associates. However, by the 1910s and especially by the 1920s, the demand for African art in Europe had already spread to other sectors of society. In France in particular, the end of World War I brought about an atmosphere that was conducive to engaging the interest of a wider public in the appreciation and collection of African art. The disdain in which Africans had previously been held by the great majority of France's population was replaced after the war "by a certain curiosity about the customs of these [African added by A.P.] people who had fought fiercely [against the Germans added by A.P.] and were now joyful partners in the victory celebrations". ${ }^{22}$ The first bloom of African art's influence on the Parisian avant-garde developed after the First World War into a commercialized version of 'buying all African things', a sort of a blackened version of Art Deco. This 'Black Deco'23 cousin was soon applied decoratively to many areas of the Parisian lifestyle: furniture was embellished with animal skins and African designs; clothing stressed natural textiles and jungle pelts; jewelry boosted precious African metals and gem patterns with contemporary designs. 'Black Deco' gradually settled into

20 S. Culin, Primitive Negro Art, Chiefly from the Belgian Congo. [Catalogue]. Brooklyn Museum: Department of Ethnology, 1923, p. 5.

21 Ch. B. Steiner, African Art in Transit, Cambridge: Cambridge University Press, 1994, p. 5.

22 J.-P. Paudrat, From Africa, in: W. Rubin, Primitivism..., vol. 1, p. 157.

23 'Black Deco' is a term coined by Rosalind Krauss for the playful transmutation of l'art negre into modern art. "The decorative application of tribalizing detail to a stylized, planar background is the formal strategy of what might be called Black Deco". R. Krauss, The Originality of the Avant-Garde and Other Modernist Myths, Cambridge, Mass: The MIT Press 1986, p. 48. 
a style ripe for marketing and black juxtaposed with classical 'white' Art Deco became the vogue. By the end of the 1920s, Paris had fallen under the magical spell of what some writers call 'Negrophilia'24, an exotic entertainment industry of musical jazz and tap-dancing performances, whose central figure was Josephine Baker (1906-1975). Most such music halls were situated in and around the Paris district of Montmartre where many painters, sculptors, musicians and writers also lived and congregated. In short, the so-called 'vogue of the Negro' became an integral part of Parisian intellectual life. ${ }^{25}$ The success of the African pavilion at L'Exposition Coloniale de Vincennes in 1931 fueled the demand for African objects in France even further. ${ }^{26}$ The pavilion building was soon converted into a permanent exhibition called the Musée des Colonies where the power of colonial France was displayed; the conquered territories were presented alongside the history of the colonial conquest and the influence of its modern art. [Fig. 2]

It is also worth mentioning a few films, such as Michel Allégret's and André Gide's Voyage au Congo [Travels in the Congo] (1928), Robert Flaherty's Nanook of the North (1922) and Leon Poirier's hit La Croisičre Noire [The Black Journey] (1926). All of them, in a more or less ethnographic way, brought Europeans closer to Sub-Saharan Africa. The movie Voyage au Congo is especially unusual for its time. It is a largely observational document, showing aspects of the lives, culture and built environments of diverse groups in the region, amongst them the Baya, Sara and Fula peoples, without trying to insert them into a dramatic narrative. We see the setting of an African village and its social life: villagers self-consciously working on their everyday chores such as grinding grain, tending fires, minding children, or participating in a village festival of dance and song. What is most striking about Allégret and Gide's film, however, is that it mostly highlights nakedness - the nakedness of black African bodies under colonial observation. In the film, African nudity structures the critical distinction between the primitive and modern, wild and civilized, nature and culture. So, once again, Africans are shown through the stereotypical cliché of 'wild' people.

24 Petrine Archer-Shaw adapts the term 'negrophilia' as meaning 'a love of black culture' from Jean Laude who used of the word 'négrophilie' in his book La Peinture française (1905-1914) et l'art nègre (Paris 1968). She also notes its usage in the title of an essay by James Clifford in A New History of French Literature (Harvard, 1989) and the title of an exhibition of black artistic memorabilia at Amsterdam's Tropenmuseum in 1989-90. P. Archer-Straw, Negrophilia: Avant-Garde Paris and Black Culture in the 1920s, London: Thames \& Hudson 2000, pp. 9-11.

25 To see more: V. Bouvet, G. Durozoi, Paris Between the Wars: Art, Style and Glamour in the Crazy Years, London: Thames and Hudson 2010.

26 A. Césaire, Discours sur le colonialisme, Paris: Présence Africaine 1950. 


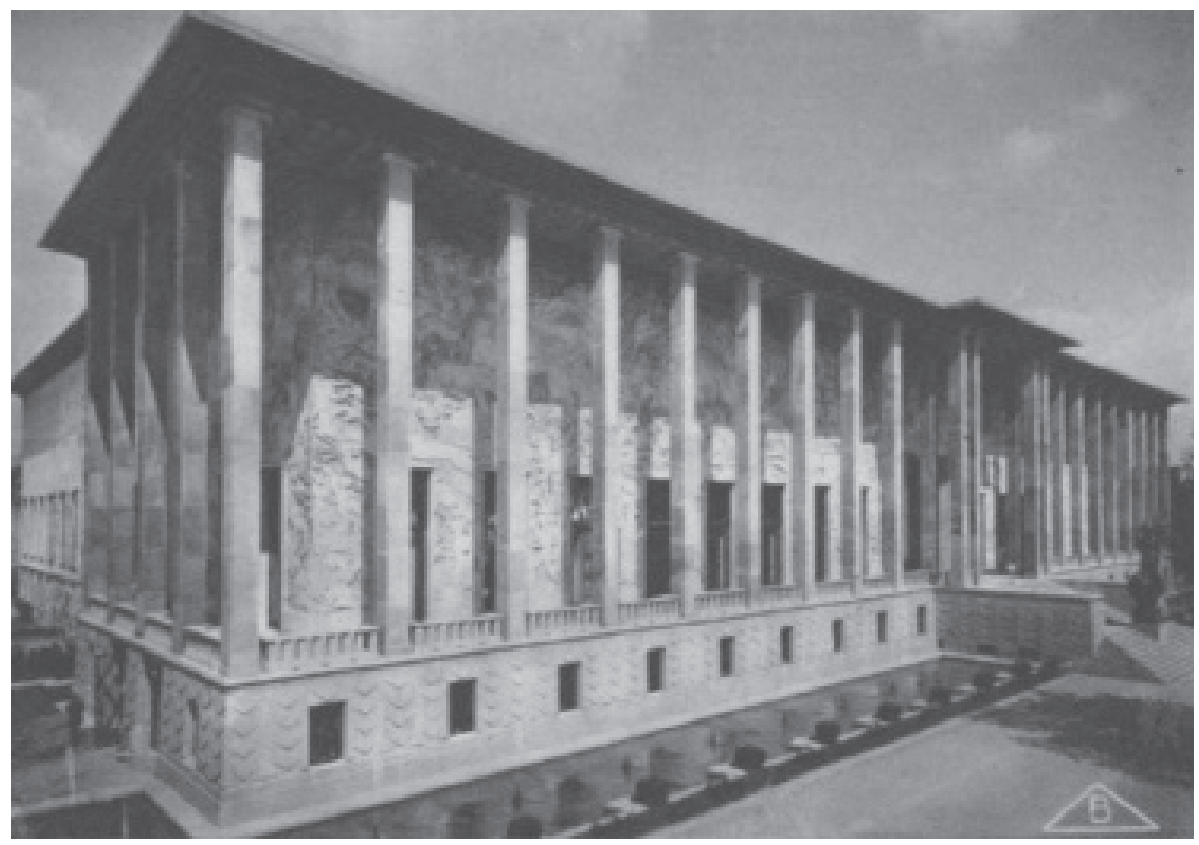

2. A postcard with the building of the Exposition Coloniale Internationale 1931, (Musée des Colonies), Paris

\section{Discours sur le colonialism - the beginning}

At this point, it is important to consider how changing perceptions of the art and culture of the Other have affected the way people from distant lands are perceived. Of course, another change after the appreciation of culture began was the abandonment of colonial policies toward non-European inhabitants. One of the first people who ruthlessly criticized colonialism and pointed to the imminent end of such perception of the world was Aimé Césaire (1913-2008). He was an influential Martinican poet, playwright and politician. He was also a co-founder, with Léopold Sédar Senghor (1906-2001), of an influential movement to restore the cultural identity of black Africans, known as Negritude. In his discourse on colonialism, first published in France in 195027, which is undoubtedly one of the key texts in post-war anti-colonial literature, Césaire presents colonialism and its impact on the colonized people, on their culture and history.

27 J. Laude, The Arts of Black Africa, Berkeley: University of California Press 1971, p. 20. 
In addition, he describes colonizers as dehumanized and brutal as a result of their actions against the Black natives. Thus, Césaire demonstrates how colonialism works to 'decivilize' the colonizer. Consequently, colonialism is dragging white people deeper and deeper into the abyss of barbarism. The instruments of colonial power rely on barbaric, brutal violence and intimidation, and the result is the degradation of Europe itself. Césaire reveals that the colonizers' sense of superiority and mission as the world's civilizers depends on turning the Other into a barbarian. Hence, Césaire can only conclude his argument with the words of Frantz Fanon (1925-1961) - "Europe is indefensible."28

Soon, other publications stigmatizing the phenomenon of colonialism appeared. These were such groundbreaking works as Jean-Paul Sartre's Black Orpheus (1948), W.E.B. Du Bois's Color and Democracy (1945) and The World and Africa (1947), Frantz Fanon's Black Skin, White Masks (1952), Albert Memmi's The Colonizer and the Colonized (1957) and Richard Wright's White Man Listen! (1957). There were also magazines fighting against the colonial policy, such as "Presence Africaine" and "African Revolution", which additionally became an outstanding voice of the Négritude movement ${ }^{29}$. Like most radical literature produced during this era, Discourse on Colonialism puts the colonial question in the foreground and center.

To summarize this paragraph, the 'discourse' descriptor in Discours sur le colonialism is double-edged: it is Césaire's discourse on material and spiritual devastation caused by colonialism, and it is a critique of colonial discourse. Such an attitude in Césaire's criticism, anticipating an explosion of works of art in the 20th and 21 st centuries, is the subject of what we now call 'postcolonial studies.'

\section{The origins of discourse on colonialism in the visual arts}

A visual counterpart of writers representative of the decolonial trend is one of the truly pioneering film essays in the history of cinema, Les statues

28 F. Fanon, The Wretched of the Earth, New York: Grove Press 1967, p. 102.

29 Négritude was an anti-colonial cultural and political movement founded by a group of African and Caribbean students in the 1930s in Paris, seeking to reclaim the value of blackness and African culture. Its leading figure was Léopold Sédar Senghor (elected first president of the Republic of Senegal in 1960) who, along with Aimé Césaire from Martinique and Léon Damas from French Guiana, began to examine Western values critically and to reassess African culture. Members of the group began to publish Revue du Monde Noir ("Review of the Black World”) in 1931 in Paris. R. Rexer, „Black and White and Re(a)d All Over: L'Étudia nt noir, Communism, and the Birth of Négritude, "Research in African Literatures" 2013, no. 4, pp. 1-14; T. Rudowski, Czym jest Négritude? Wprowadzenie do zagadnienia murzyńskości, "Ameryka Łacińska. Kwartalnik analityczno-informacyjny” 2013 nos. 3-4, pp. 77-100. 
meurent aussi [Statues Also Die 1953]. It is a French documentary directed by Chris Marker and Alain Resnais. The film presents a record of Chris Marker's visit to the Parisian museum of African art - the ethnological Musée de l'Homme. Here, through the careful eye of the camera, the artist records an array of sculptures, masks and other examples of traditional works from SubSaharan Africa. The narrator focuses on emotions evoked by the works of art and discusses the perception of exotic art from a historical and contemporary European perspective. According to professor Nora M. Alter, the film, entitled Les statues meurent aussi in French, "illustrates the process whereby a religious fetish is transformed into a commodity fetish by Western civilization." ${ }^{30}$ In other words, this 30-minute film essay explores historical African art and how colonialism influences its perception. In the film's final commentary, a clearly revolutionary statement in its original historical context, it is stated: "There is no break between African and our civilization. Faces of the African art are shed by the same human laces, like snake's skins." ${ }^{31}$ It is worth mentioning that the sensitive subject, namely harsh criticism of colonialism, urged the French Centre National de la Cinematographic [National Center of Cinematography] to censor the film until 1963.

A simultaneously impressive and very important as well as entirely new perspective was set down in 1947 by André Malraux (1901-1976), a French novelist and art theorist, in his monumental book - Imaginary Museum ${ }^{32}$. Long before more recent discussions on globalization, he considered art to be internationally related, global. Aesthetically, Malraux compared works of art from everywhere without chronology, placing them in historical terms at best. $\mathrm{He}$ took pictures and works of art, commissioned pictures of distant and hard-toreach sculptures and sculpture fragments, temples and temple fragments, and compared them. It was an amazing idea for the harmonious coexistence of works of art over the centuries, in different cultures and geographical locations; Malraux discovered similarities among them. [Fig. 3]

Other visual phenomena that took up decolonial themes in the 1950s include the creative output of Ben Enwonwu (1917-1994), a celebrated Nigerian modernist painter. He grew up in Onitsha, a cosmopolitan market town that was a center of indigenous Igbo culture and the British colonial rule. Enwonwu is an important figure of early Nigerian Modernism, as his paintings and an extensive archive of speeches, articles, letters, and unpublished biographical writings offer an unprecedented insight into the mind of an African artist who-

30 N. M. Alter, Chris Marker, Chicago: University of Illinois Press 2006, p. 60.

31 Ibid.

32 A. Malraux, Le musée imaginaire, [3ème edition], Paris: Gallimard 1965 


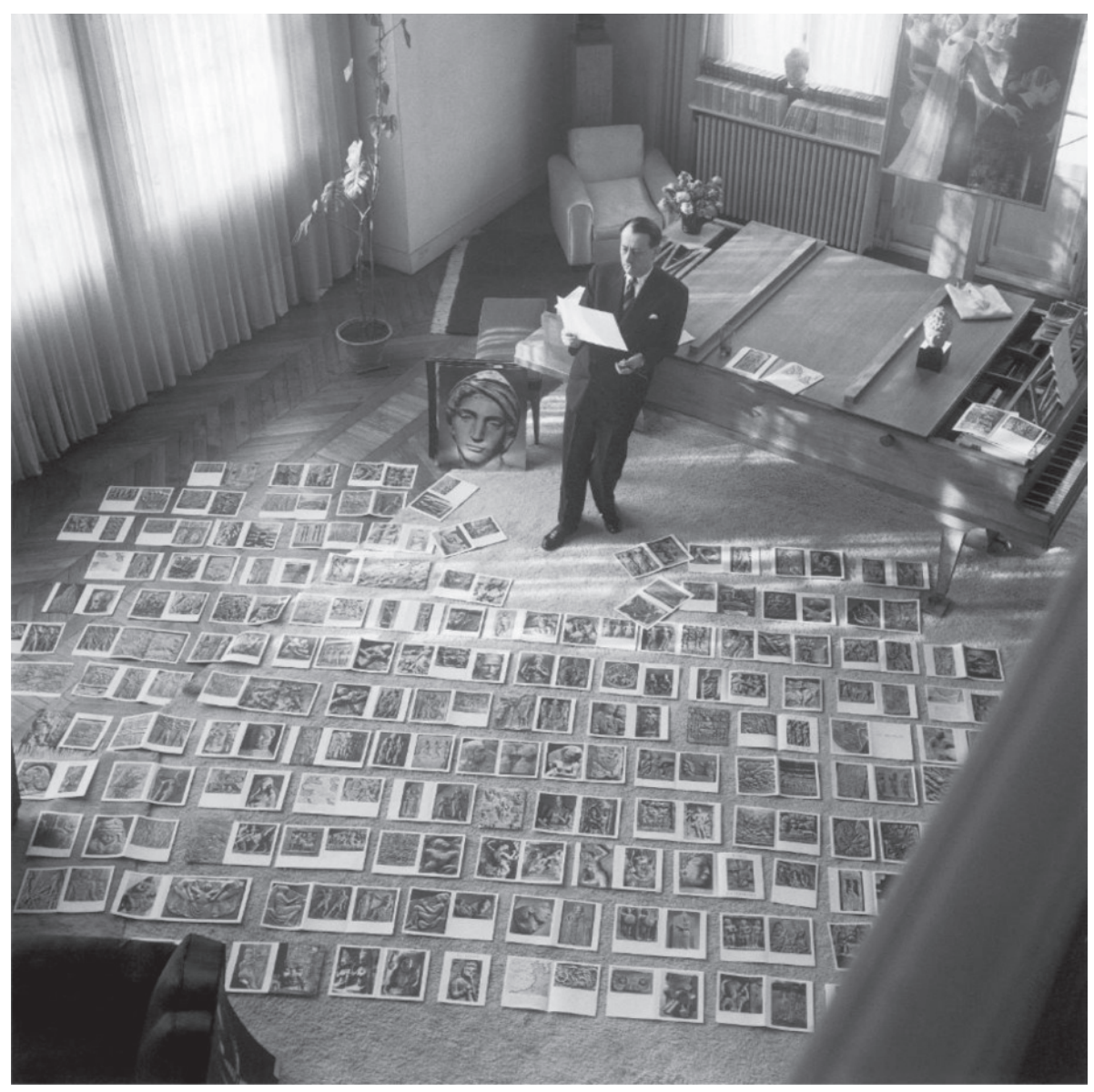

3. André Malraux, while working on the book Imaginary Museum. Malraux posed at home for the photographer Maurice Jarnoux from the magazine "Paris Match," 1954, Paris (https:// www.christies.com/features/Walter-Grasskamp-The-Book-on-the-Floor-Andre-Malraux-and-theImaginary-Museum-8060-1.aspx)

se identity got divided in direct response to colonialism ${ }^{33}$. In his papers, he discussed and debated what it means to be an 'African artist' and what 'contemporary African art' is - these are discussions that continue to the present

33 S. O. Ogbechie, B. Enwonwu, The Making of an African Modernist, New York: Rochester 2008; B. Gassmann de Sousa, Decolonising Nigerian Modernism: Ben Enwonwu's, "Identity in Politics. Tate Papers" 2018, no. 30, Autumn, https://www.tate.org.uk/research/publications/tate-papers/30/decolonising-nigerian-modernism-ben-enwonwus-identity-politics $(13 / 06 / 2021)$. 


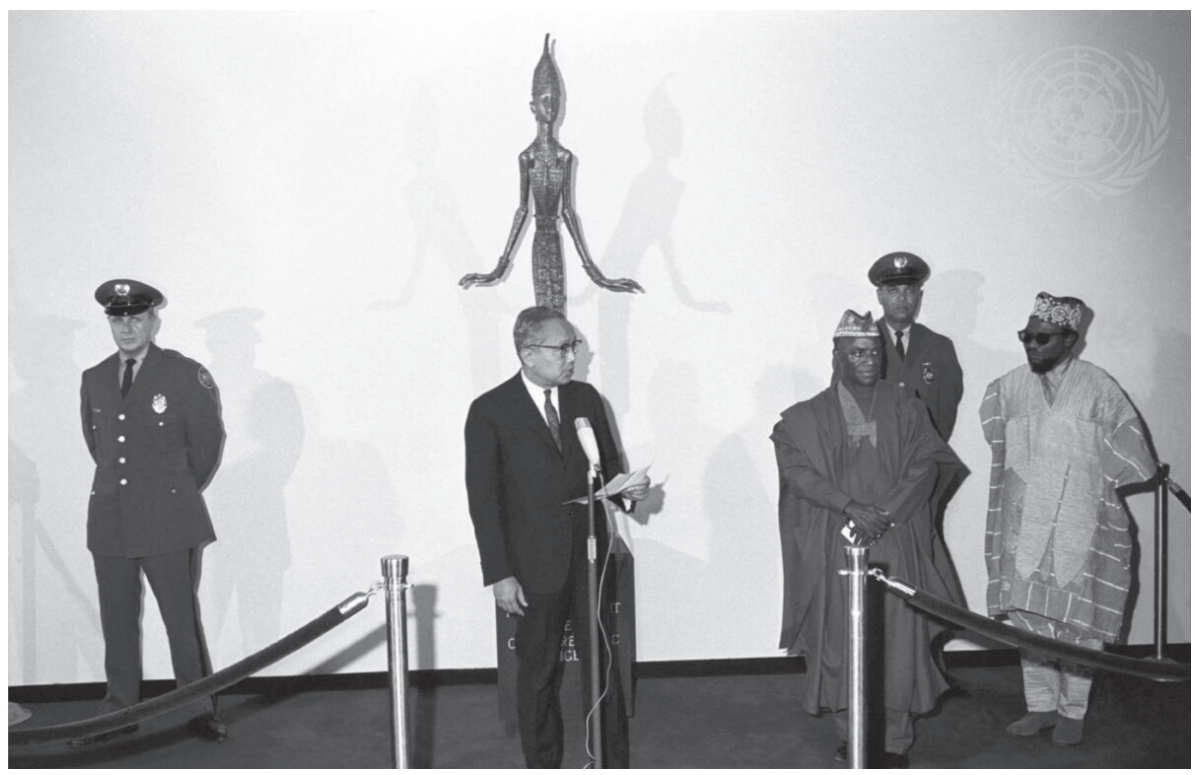

4. The bronze sculpture Anyanwu/Awakening by the Nigerian artist Ben Enwonwu was unveiled on 10th May 1966 at the United Nations Headquarters (https://www.unmultimedia.org/s/ photo/detail/126/0126482.html)

day. Enwonwu believed throughout his life that modern Nigeria needed to be rooted in its heritage and culture. Therefore, he based his art on a complex amalgamation of visual imagery and systems of representation, borrowing from local traditions and, to a lesser extent, from foreign culture. An example of Enwonwu's work that breaks the barriers of racism is one of his bronze sculptures entitled Anyanwu/Awakening (1954-1955). This sculpture, inspired by the Igbo earth-goddess Ani, was a gift from newly independent Nigeria in support of world peace and the liberation of colonies. This figure follows the simplicity of modernist sculpture, especially that of Giacometti, from its base to its elongated torso. Drawing from the ichi scarification patterns traditionally worn by Igbo men, Enwonwu adorned Anyanwu's garments and headdress with lines that radiate from a central axis. The slender arms are positioned in a symmetrical gesture that, when coupled with the attenuated form and aggrandizing headdress, forms an overall sinuous figure. For more than six decades, the sculpture has occupied a prominent place in the lobby of the UN headquarters in New York. [Fig. 4]

It is worth mentioning that there is no clear definition of so-called 'colonial modernism' or of the difficult nature of modernity in African art, i.e. which artists create it, in which years (and of which trends) it was formed and 
then developed. Moreover, the definition of 'colonial modernism' as a peripheral and, qualitatively speaking, less modernist exception, effectively renders it 'absent' from the canon of World modernism. An illustration of this problem is the figure of the black artist Ernest (Methuen) Mancoba (1904-2002) who was an avant-garde painter born in South Africa. In 1938, Mancoba emigrated from Africa to Paris and later, in 1947, to a small town outside of Copenhagen. ${ }^{34}$ There he was one of the cofounders of the CoBrA avant-garde movement (active from 1948 to 1951). However, his figure was consistently excluded, for racist reasons, from catalogues and later studies concerning this important group of abstractionists. ${ }^{35}$

\section{Postcolonial debate in contemporary culture and art}

The 1980s and 1990s saw many changes in the way art from outside Europe was presented. Before the end of the 1980s, only the Venice Biennale offered a unique international forum for the showcasing of new works by contemporary artists. In the past three decades, however, yearly and biannual events devoted to exhibiting the works of distinguished and emerging artists have been established in many cities around the world, most notably in Basel. It is worth mentioning such landmark exhibitions as the scholarly, important and influential (from a curatorial perspective) 1984/85 exhibition "Primitivism in Modern Art: Affinities of the Tribal and the Modern" which treated African and oceanic works as it would any sophisticated modernist object. ${ }^{36}$ Another important exhibition was the controversial "Magiciens de la Terre" from 1989, which set a different course in its response to the issue that had vexed the modernist museum from its earliest inception, namely, the status and place of non-Western art within the history of modernism and contemporary art. To evade this conundrum, the show curator Jean-Hubert Martin elected to eliminate the word artist from his exhibition, mindful of the fact that such a designation might be unduly burdened by a Western bias, choosing instead the term Magiciens as a proper name for the object and image makers invited to present their art. Ano-

34 E. Miles, Lifeline Out of Africa: The Art of Ernest Mancoba. Cape Town: Human \& Rousseau 1994, p. 9.

35 In his article on the problematic nature of modernity in African art, Rasheed Araeen states: "What is extraordinary about Mancoba's achievement is that he is very likely the first artist from the whole colonized world - Africa, Asia, the Americas, Australasia, and the Pacific - to enter the central core of modernism at the time when this world, particularly his own country of South Africa, was still struggling under colonialism, and to challenge modernism's historical paradigm on its own terms" in: R. Araeen, Modernity, Modernism and Africa's Authentic Voice, "Third Text" 2010, vol. 24, no. 2, p. 286.

36 W. Rubin, Modernist Primitivism: An Introduction, in: W. Rubin, Primitivism...,vol. 1, pp. 11-28. 
ther ground seems to have been broken when the Senegalese figurative sculptor Ousmane Sow and the Nigerian installation artist Mo Edoga (1952-2014) became the first Africans to be included in the prestigious exhibition Documenta ${ }^{37} 9$ (1992). Since then, African artists have participated in all the subsequent Documenta exhibitions (Documenta 10,11 and 12) which are regularly held every five years in Kassel, Germany. It seems that the visibly growing process of engaging curators of African origin (such as Okwui Enwezor - the first nonEuropean director, Chika Okeke-Agulu, Ugochukwu-Smooth, C. Nzewi, Missla Libsekal and Rujeko Hockley) in the creation of exhibitions of modern African art, particularly as a strategy to incorporate the voices of those represented, is one of the most important aspects of the "curatorial turn" of the 21st century, presented by Irit Rogoff in her significant essay entitled Turning. ${ }^{38}$

Such exhibitions have helped to create significant visibility for modern and contemporary African art in the international arena. They have articulated the broad contexts of African artistic modernity in the 20th century, employing those exhibitions as epistemological frameworks for engaging the intersection of African history and art history. ${ }^{39}$

Other important issues that should be considered in the 21 st century are questions such as: what is our understanding of decolonizing art history now? What does decolonized art history look like? How should it be written and practised? How might decolonization of art history impact your area of research/practice? What strategies might different spaces for decolonization demand? Can a Colonial Archive be an Anti-Colonial Archive? ${ }^{40}$

37 Documenta is an exhibition of contemporary art that takes place every five years in Kassel, Germany. It was founded by the artist, teacher and curator Arnold Bode in 1955 as part of the Bundesgartenschau (Federal Horticultural Show) which took place in Kassel at that time and was an attempt to bring Germany up to speed with modern art, both banishing and repressing the cultural darkness of Nazism. This first Documenta featured many artists who are generally considered to have had a significant influence on modern art (such as Picasso and Kandinsky). The more recent Documentas featured art from all continents; nonetheless, most of it is site-specific. Every Documenta is limited to 100 days of exhibition, which is why it is often referred to as the "museum of 100 days". Each is generally regarded as a highly prestigious and celebrated event in the art world: https://www.documenta.de/en/ about\#16_documenta_ggmbh (21/10.2020).

38 I. Rogoff explains that a turn - such as that toward linguistics in the 1970s - occurs when an academic discipline is in urgent need of being shaken up, perhaps to the point of discomfort. I. Rogoff, Turning, in: P. O'Neill, M. Wilson (ed.), Curating and the Educational Turn, London: Open Editions 2010, pp. 32-46.

39 R. Chikukwa, Curating contemporary African art: questions of mega-exhibitions and Western influences, "African Identities" 2011, vol. 9, no. 2, pp. 225-229.

40 Such a discussion is taking place at the University of Texas at Austin, regarding Benson Library resources, https://arcade.stanford.edu/blogs/can-colonial-archive-be-anti-colonialarchive-centennial-nattie-lee-benson-library-ut-austin?fbclid=IwAR2QWs4Az0t_yUMgCovuGOripGIMSyBBJN3SK5htReqrmiIXwyciRHSYQPY, (13/06/2021). 
Since these problems are very urgent issues in recent times, in 2020 two researchers related to the Association for Art History - Catherine Grant and Dorothy Price - proposed a discussion on the topic of decolonizing art. In a subsequent paper ${ }^{41}$, the researchers offer the results of surveys and interviews they conducted with curators and contemporary art historians via social media, using the domain \#DecolonizingArtHistory. Among many important issues, a crucial statement was made by one of the interviewees - Tim Barringer, distinguished professor of History of Art from Yale University. He believes that art history is imperial and will never be 'innocent' and objective:

"Art history can decolonize itself only to the extent that it acknowledges that Euro-colonial art and our discipline itself are themselves products of empire. Powerful symbols of racial oppression such as the Rhodes statue ${ }^{42}$, or the naming of a Yale residential college after John C. Calhoun, are legitimate targets for contestation and removal. But even if such emblems are erased, the history of art cannot deny its intellectual inheritance: it has developed as an academic discipline since the eighteenth century with racialized concepts at its core. It is a dissimulation to behave as if art history were a colonized territory fighting for independence and a return to an indigenous condition innocent of ideological corruption. Art history is never innocent." 43

It is hard not to agree with these words, teaching art history in Poland. So far (as of June 2021) 44 $^{4}$, courses in non-European art are only to be found in the syllabuses of art history at Mikołaj Kopernik University in Torun and at the University of Łódź. Moreover, judging from conversations conducted with, for example, students from the Erasmus program, focus on the issues of European art is common in other European countries, such as Spain, Italy, Portugal, Germany, Slovakia, France, Russia, Belarus and Lithuania. ${ }^{45}$ Thus,

41 C. Grant, D. Price, Decolonizing Art History, https://onlinelibrary.wiley.com/doi/epdf/10.1111/1467-8365.12490, (13/06/2021).

42 In 2015, students at the University of Cape Town began to protest the prominent presence of a statue of the British colonialist - Cecil Rhodes - on their campus, using \#RhodesMustFall. After a dynamic campaign, the statue was removed to a museum. Rhodes statue removed in Cape Town as the crowd celebrates, https://www.bbc.com/news/world-africa-32236922, $(13 / 06 / 2021)$.

43 C. Grant, D. Price, Decolonizing Art..., pp. 11-12.

44 Information based on the analysis of course websites and the author's observations: http:// informatorects.uw.edu.pl/pl/programmes-all/HS/S1-HS/\#certyfikaty (13/06/2021); https:// www.otouczelnie.pl/uczelnia_dzial/2461/Historia-sztuki (13/06/2021).

45 The author's observations are based on conversations with art history students from the Erasmus program staying at the University of Łódź between 2011 and 2021. The interviews were conducted in the form of semi-structured interviews lasting approximately one hour each. 
from the very beginning, students are profiled in a certain way, so that they automatically associate beauty with the aesthetics of the Western world. However, as was mentioned above, since the 1920s there has been a certain shift in the presentation of artefacts from Africa or Asia. Still, as Nicholas Mirzoeff, a contemporary visual culture theorist, notes, white culture and art are privileged in museum settings. The theorist presents an example from the Metropolitan Museum in New York:

“(...) they [white marble statues of Greece and Rome, added by A.P.] are placed in light, high-ceilinged rooms right next to the entrance. African objects, of which the Met has an amazing collection, appear in dark, gloomy spaces. Native American work? One small gallery, which is as far away from the $<<$ American > wing as it can physically be." ${ }^{46}$

\section{What is Colonial Art and How to Present It}

It seems that the problem of presenting art that is defined as postcolonial raises even more problems than placing traditional works of art from Asia, Africa or Oceania within the space of a Western art museum. Curating postcolonial art exhibitions is in and of itself a problematic endeavour. Why is it so? The postcolonial concept is not a finished product: it is happening, in motion, and therefore cannot be accurate. This type of art analyses and responds to the cultural heritage of colonialism and the human consequences of controlling a country to exploit the native people and their land. In doing so, it also refers to how the society and culture of a non-European people were seen from the perspective of Western cultural knowledge and how it was used to subjugate the people into a colony of the European Mother Country.

The recently deceased Okwui Enwezor (1963-2019), an influential Nigerian curator whose large-scale exhibitions displaced Western art from the centre stage and who himself shaped a new approach to postcolonial art in the age of globalization, has written about the problems of exhibition curation, pointing out that:

"It has been long recognized that postcolonial processes have increasingly highlighted the problematics of Western judgment over vast cultural fields in the non-Western world. Many curatorial practices today are direct responses to the postcolonial critique of Western authority. What I am trying to foreground here is the fact that the conditions of production and reception of contemporary art

46 N. Mirzoeff, Empty the Museum, Decolonize the Curriculum, Open Theory, "Nordic Journal of Aesthetics" 2017, no. 53, p. 14. 
evince a dramatic multiplication of its systems of articulation to the degree that no singular judgment could contain all its peculiarities." 47

Enwezor's show, "In/Sight: African Photographers, 1940 to the Present" (1996) in the Solomon R. Guggenheim Museum in New York, was one of the first museum exhibitions to present imagery from Africa by Africans themselves, beyond the stereotypes of Western ethnography. In 1998, at the age of 34, Enwezor was named artistic director of the forthcoming 11th edition of Documenta, one of the world's best-attended art shows. The next landmark exhibition presented by the Nigerian curator was "The Short Century" at the Villa Stuck in Munich in 2001, and later at MoMA PS1 in New York. This broad demonstration of African art and independence movements interwove the work of four dozen living artists with archival materials, music and photography from popular magazines.

The influential UK website Art UK lists artists practicing postcolonial art. Among the mentioned artists, one can find Fred Wilson (b. 1954), Sonia Boyce (b. 1962), Kara Walker (b. 1969), Hew Locke (b. 1959) and well-known Yinka Shonibare (b. 1962) ${ }^{48}$. It can be said that postcolonial art is art relating to the times after the given nation became independent from its colonial ruler.

In my opinion, this group should include an excellent example of a conscious postcolonial artist - Kader Attia (b. 1970). He grew up in various places, moving from Paris, France to Algeria and later on spent several years in Congo. During his stay in Congo, as part of a team preparing the opening of the country's first national museum in the capital, Brazzaville, he came across objects that were to be displayed: masks, talismans, jewellery and shields. He became aware of the spiritual dimension of these objects and realized that they had mysterious and magical powers. When Attia returned to France and went looking for African artefacts in museums, he found them displayed in the building of Musée National des Arts d'Afrique et d'Océanie. Important treasures that had been blessed by healers and sorcerers, and used in rituals, were in his opinion "orphans here, because the bodies and communities that celebrated them were no longer around." ${ }^{49}$ In his subsequent works, Attia very often returned to issues typical of postcolonial history, presenting an object brutally torn out of its natural environment and enclosed in the shop window of a European

47 O. Enwezor, The Postcolonial Constellation: Contemporary Art in a State of Permanent Transition, "Research in African Literatures" 2003, no. 4, Winter, p. 69.

48 https://artuk.org/discover/stories/postcolonial-art-eight-artists-addressing-empire-colonialhistories-and-black-identities\#, (13/06/2021).

49 F. Nayeri, We Need to Talk About Colonialism, This Artist Says, New York Times, Feb. 25, 2019, [https://www.nytimes.com/2019/02/25/arts/design/kader-attia-hayward-gallery.html] 
museum. He dedicated his exhibitions "Measure and Control,"(2013) and the latest "Shifting Borders" presented in 2019 at the Hayward Gallery to these issues. [Fig. 5]

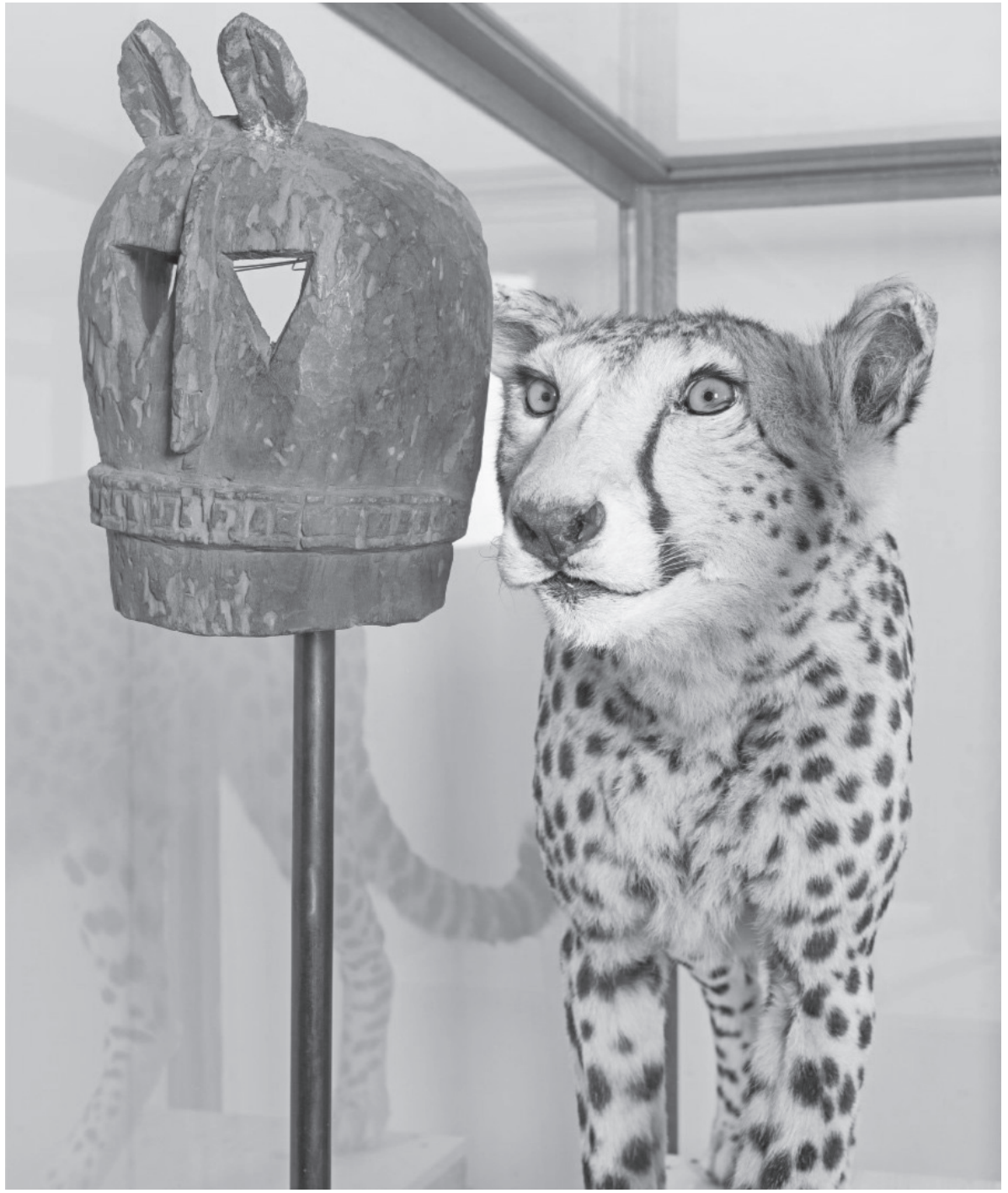

5. Kader Attia, "Measure and Control," 2013, Photograph by Ela Bialkowska 
The problem where to display colonial art collections is related to the growing demands of today's independent countries for reparations for artworks looted from them in the 19th and 20th centuries. Peru, Egypt, Nigeria and Be$\operatorname{nin}^{50}$, among others, are claiming their national treasures.

In response to these demands, some museums possessing disputed works of art argue that these items are too fragile to transfer abroad. Others say that some pieces, e.g. the Egyptian Rosetta Stone, are so iconic that they belong to the world. In 2010, the head of Nigeria's Museum and Monuments Commission, Yussef Abdullah Usman, commented on that with irony: "We are not saying these things should not be enjoyed by everyone," he said, "but I think they will be better understood if they are exhibited within the cultural milieu in which they were created." ${ }_{51}$

\section{$* * *$}

The modern world is colourful and diverse. Contemporary media easily present various conflicting views of scientists, artists and ordinary citizens. Therefore, it is necessary to develop a variety of opinions and research positions. This makes discourse on art and its products more complex and meandering. Today, the lines from Kipling's poem The White Man's Burden, created in honour of colonizers who conquer the world, sound like an accusation of thousands or even millions of dominated and displaced 'natives'. But it can be said with confidence that contemporary decolonized art history should always contain multiple narratives, so that it deals with different histories and not a story that becomes canon.

\section{BIBLIOGRAPHY:}

Adam Hochschild (2012) Duch króla Leopolda. Opowieść o chciwości, terrorze i bohaterstwie w kolonialnej Afryce, tłum. R Tarczyński, Warszawa: Świat Książki.

African Art Exhibition of 1923, https://www.brooklynmuseum.org/opencollection/research/ pna1923, (13/01/2020).

Alter Nora M. (2006) Chris Marker, University of Illinois Press, Chicago.

50 On November 23, 2018, President Emmanuel Macron of France announced that the Quai Branly Museum in Paris would return 26 works of art to Benin. More: A. Pawłowska, Rozliczenie z kolonializmem, czyli oddaj zrabowana sztuke, https://www.youtube.com/watch?v=vgvTA9J6w_U, (12/08/2021).

51 Countries Want National Treasures Returned Home, “The Americas" April 07, 2010, https://www.voanews.com/americas/countries-want-national-treasures-returned-home, $(13 / 06 / 2021)$. 
André Malraux (1965) Le musée imaginaire, [3ème edition], Paris: Gallimard.

Archer-Straw Petrine (2000) Negrophilia: Avant-Garde Paris and Black Culture in the 1920s, London: Thames \& Hudson.

Bouvet Vincent, Gérard Durozoi (2010) Paris Between the Wars: Art, Style and Glamour in the Crazy Years, London: Thames and Hudson.

Césaire Aimé (1950) Discours sur le colonialisme, Paris: Présence Africaine.

Césaire Aimé (2000) Discourse on Colonialism, trans. Joan Pinkham, New York: Monthly Review Press.

Chikukwa Raphael (2011) Curating contemporary African art: questions of mega-exhibitions and Western influences, “African Identities”, no. 2, pp. 225-229.

Conrad Joseph (1899) The Heart of Darkness. In: Blackwood's Magazine, February - April, vol. CLXV, pp. 164-460, 460-621, 620-781.

Countries Want National Treasures Returned Home, “The Americas” April 07, 2010, https://www. voanews.com/americas/countries-want-national-treasures-returned-home, (13/06/2021).

Culin, Stewart (1923) Primitive Negro Art, Chiefly from the Belgian Congo. [Catalogue]. Brooklyn Museum: Department of Ethnology.

Enwezor Okwui (2003) The Postcolonial Constellation: Contemporary Art in a State of Permanent Transition, "Research in African Literatures" no. 4, pp. 57-82.

Fanon Frantz (1967) The Wretched of the Earth, New York: Grove Press.

Flam Jack, Deutch Miriam (ed.) (2003) Primitivism and Twentieth-Century Art. A Documentary History, Berkeley-Los Angeles-London: University of California Press.

Gassmann de Sousa Bea (2018) Decolonising Nigerian Modernism: Ben Enwonwu's, "Identity in Politics. Tate Papers", no. 30, Autumn, https://www.tate.org.uk/research/publications/tate-papers/30/decolonising-nigerian-modernism-ben-enwonwus-identity-politics (13/06/2021).

Goldwater Robert (1986), Primitivism in Modern Art, Cambridge-Massachusetts-London: Harvard University Press.

Grant Catherine, Dorothy Price (Decolonizing Art History, https://onlinelibrary.wiley.com/doi/ epdf/10.1111/1467-8365.12490, (13/06/2021).

https://artuk.org/discover/stories/postcolonial-art-eight-artists-addressing-empire-colonialhistories-and-black-identities\#, (13/06/2021).

Kenedy Dane (2016) Decolonization: A Very Short Introduction, London: Oxford University Press.

Kipling Rudyard (1890) The White Man's Burden, "Literature”, February 4, p. 115. 
Kohn Margaret (2021) Colonialism, in: Edward N. Zalta (ed.), Stanford Encyclopedia of Philosophy, Palo Alto: Stanford University Press https://plato.stanford.edu/entries/colonialism/ $(13 / 06 / 2021)$.

Lack Jessica (2000) Global Art, London: Thames \& Hudson Ltd.

Laude, Jean (1971) The Arts of Black Africa, Berkeley: University of California Press.

Liebersohn Harry M (2016) Introduction: The Civilizing Mission, “Journal of World History” vol. 27 , no. 3 , pp. 383-387.

Macke Auguste (2002) Masks, in: Harrison, Charles \& Paul Wood (ed.). Art in Theory, 1900-2000: an anthology of changing ideas, Oxford: Wiley-Blackwell, pp. 95-96.

Miles Elisa (1994) Lifeline Out of Africa: The Art of Ernest Mancoba, Cape Town: Human \& Rousseau.

Nayeri Farah (2019) We Need to Talk About Colonialism, This Artist Says, "New York Times," Feb. 25, [https://www.nytimes.com/2019/02/25/arts/design/kader-attia-hayward-gallery.html] $(13 / 06 / 2021)$

Nicholas Mirzoeff (2017) Empty the Museum, Decolonize the Curriculum, Open Theory, "Nordic Journal of Aesthetics", no. 53, pp. 6-22.

Ogbechie Sylvester Okwunodu, Ben Enwonwu (2008) The Making of an African Modernist, New York: Rochester.

Paudrat Jean-Louis (1984) From Africa, in: Rubin William (ed.) Primitivism in 20th Century Art: Affinity of the Tribal and the Modern, New York: The Museum of Modern Art, vol. 1, pp. 75125.

Pawłowska Aneta (2009) Picasso i Afryka, "The Artistic Traditions of non-European Culture" no. 1, pp. 163-173.

Pawłowska Aneta (2017) Avant-gardists and primitivism "Art Inquiry. Recherches sur les arts, vol. XIX, pp. 153-169.

Pawłowska Aneta, Rozliczenie z kolonializmem, czyli oddaj zrabowana sztuke, https://www.youtube.com/watch?v=vgvTA9J6w_U, (12/08/2021).

Rasheed Araeen (2010) Modernity, Modernism and Africa's Authentic Voice, “Third Text”, vol. 24, no. 2, pp. 277-286.

Renan Ernest (1929) La Reforme Intellectuelle et Morale, Paris: Calmann-Levy.

Rexer Raisa (2013) Black and White and Re(a)d All Over: L'Étudiant noir, Communism, and the Birth of Négritude, "Research in African Literatures" no. 44(4), pp. 1-14.

Reybrouck, van David (2016) Kongo. Opowieść o zrujnowanym kraju, tłum. J. Jędryas, Warszawa: Grupa Wydawnicza Foksal. 
Rhodes statue removed in Cape Town as the crowd celebrates, https://www.bbc.com/news/worldafrica-32236922, (13/06/2021).

Robinson Cedric (2000) Black Marxism: The Making of the Black Radical Tradition, Chapel Hill, NC: University of North Carolina Press.

Rogoff Irit (2010), Turning, in: O'Neill, Paul \& Wilson Mick (ed.). Curating and the Educational Turn, London: Open Editions, pp. 32-46.

Rosalind Krauss (1986) The Originality of the Avant-Garde and Other Modernist Myths, R. Krauss, The Originality of the Avant-Garde and Other Modernist Myths, Cambridge, Mass: The MIT Press.

Rousseau Jean-Jacques (2017) The Social Contract, J. Bennett (ed.), www.earlymoderntexts. com/assets/pdfs/rousseau1762.pdf, (13/06/2021).

Rubin William (1984) Modernist Primitivism: An Introduction, in: Rubin William (ed.) Primitivism in 20th Century Art: Affinity of the Tribal and the Modern, New York: The Museum of Modern Art, vol. 1, pp. 11-28.

Rubin William (ed.) (1984) Primitivism in 20th Century Art: Affinity of the Tribal and the Modern, New York: The Museum of Modern Art, vol. 1-2.

Rudowski Tomasz (2013) Czym jest Négritude? Wprowadzenie do zagadnienia murzyńskości, “Ameryka Łacińska. Kwartalnik analityczno-informacyjny”, nos. 3-4, pp. 77-100.

Steiner Christopher B. (1994) African Art in Transit, Cambridge: Cambridge University Press, 1994.

Wierzbicka Ewa (2011) "Misja cywilizacyjna" Belgów w Kongo, "Historia i Polityka" no. 6, pp. 187-201.

Zarobell John (2017), Art and the Global Economy, Berkeley: University of California Press.

\section{„BRZEMIĘ BIAŁEGO CZŁOWIEKA”. OD KOLONIALIZMU DO POSTKOLONIALIZMU - DYSKURS O SZTUCE POZA- EUROPEJSKIEJ I JEJ ZNACZENIU W ŚWIECIE SZTUKI Z PERSPEKTYWY LAT 20. XX WIEKU. (streszczenie)}

Artykuł podejmuje w perspektywie historycznej ocenę wpływu XIX- wiecznej kolonizacji europejskiej na kulturę i sztukę. Omawiane są kolejne przekształcające się podejścia do ludności pozaeuropejskiej od poczucia misja cywilizacyjna białych w XIX w. (co odzwierciedla wiersz Brzemię białego człowieka), poprzez zainteresowanie sztuka plemienną europejskiej awangardy na początku XX w., aż do okresu początku dyskursu nad negatywnym obliczem kolonializmu (np. Discours sur le colonialism autorstwa Aimé Césaire'a czy wizualne działania Bena Enwonwu, Ernesta Mancoba). Szczególna uwaga została poświęcona czasom współczesnym i rozli- 
czeniu z kolonializmem. Trend ten jest coraz bardziej widoczny od schyłku lat 80 . XX wieku (np. kontrowersyjna wystawa Magiciens de la Terre (Paryż) z 1989 r. czy wystawy z cyklu Documenta, których kuratorami byli nie-Europejczycy (np. Okwui Enwezor). Okres wieku XXI jest zdominowany przez trend postcolonialny w sztuce (uznani artyści o tym profilu to: Fred Wilson (ur. 1954), Sonia Boyce (ur. 1962), Kara Walker (ur. 1969), Hew Locke (ur. 1959), Yinka Shonibare (ur. 1962), Kader Attia (ur. 1970)).

Słowa kluczowe: postkolonializm, podbój kolonialny, dyskurs, sztuka, Afryka, kolekcje

Aneta Pawłowska - PhD after habilitation, Faculty of Philosophy and History, Institute of History of Art, University of Łódź. She specializes in South African art and culture. Her research interests include: contemporary art, 20th century gender art and history and theory of collections. Her current research focuses on Audio description. Selected publications Sztuka $i$ kultura Afryki Potudniowej. W poszukiwaniu tożsamości artystycznej na tle przeksztatceń historycznych [Art and Culture of South Africa. In search of artistic identity of South Africa, as influenced by historical transformations], Łódź: Wydawnictwo Uniwersytetu Łódzkiego 2013; Studia o sztuce polskiej, Łódź: Wydawnictwo Uniwersytetu Łódzkiego 2017; Andrzej Jocz (1941-2019) ocalić od zapomnienia, Łódź: Wydawnictwo Uniwersytetu Łódzkiego 2021. 